\title{
GIS-Based Evaluation of Water Quality Index of Groundwater Resources in West Bokaro coalfield, India
}

\section{ASHWANI KUMAR TIWARI*, PRASOON KUMAR SINGH and MUKESH KUMAR MAHATO}

\author{
Department of Environmental Science \& Engineering, \\ Indian School of Mines, Dhanbad-826004, Jharkhand, India.
}

http://dx.doi.org/10.12944/CWE.9.3.35

(Received: July 15, 2014; Accepted: September 05, 2014)

\begin{abstract}
Water Quality Index (WQI), a technique of rating water quality, is an effective tool to assess quality and ensure sustainable safe use of water for drinking. The present work is aimed to assess the groundwater quality of West Bokaro coalfield region for knowing the suitability of drinking purpose by calculating the WQI and using Geographical Information System (GIS) techniques. Thirty three groundwater samples were collected from dug wells during post-monsoon, 2012 for comprehensive physico-chemical analysis. Ten parameters were considered for calculating the WQI such as: $\mathrm{pH}$, fluoride $\left(\mathrm{F}^{-}\right)$, chloride $(\mathrm{Cl})$, nitrate $\left(\mathrm{NO}_{3}^{-}\right)$, sulphate $\left(\mathrm{SO}_{4}{ }^{2-}\right)$, bicarbonate $\left(\mathrm{HCO}_{3}{ }^{-}\right)$calcium $\left(\mathrm{Ca}^{2+}\right)$, magnesium $\left(\mathrm{Mg}^{2+}\right)$, total hardness (TH) and total dissolved solid (TDS). The spatial distribution maps of the above mentioned parameters were prepared by using GIS, software. The computed WQI value ranges from 21 to 131 with an overall average of WQI value 73 . More than half of the locations fall in Excellent to Good category indicating the groundwater in the study area is suitable for drinking purposes.
\end{abstract}

Key words: Water quality index, Groundwater, West Bokaro coalfield, GIS.

\section{INTRODUCTION}

Groundwater is the major source for drinking and domestic purposes in both rural and urban areas. Besides, it is an important source for both agriculture and industrial sectors.In the last few decades, there has been a tremendous increase in the demand for fresh water due to the rapid growth of population and the accelerated pace of industrialization. Rapid urbanization, especially in developing countries like India, has affected the availability and quality of groundwater due to its overexploitation and improper waste disposal, especially in urban areas (Ramakrishnalah et al. 2009) .Once the groundwater is contaminated, its quality cannot be restored by stopping the pollutants from the source therefore it becomes very important to regularly monitor the quality of groundwater and to device ways and means to protect it (Mufid al-hadithi 2012). Water pollution not only affects water quality, but also threats human health, economic development, and social prosperity
(Milovanovic2007). Access to drinking water in India has increased over the past few decades with the tremendous adverse impact of unsafe water for health (Singh et al. 2013). According to World Health Organization (WHO), about $80 \%$ of all the diseases in human beings are caused by water. It is estimated that about $21 \%$ of the communicable diseases in India are water borne (Bradon and Homman1995). Scarcity of clean and potable drinking water has emerged in recent years as one of the most serious developmental issues in many parts of West Bengal, Jharkahnd, Orissa, Western Uttar Pradesh, Andhra Pradesh, Rajasthan and Punjab (Tiwari \& Singh 2014).

Water Quality Indexis an important way to assess the quality of groundwater in the recent years. WQI is an a superior way to the understanding of water quality issues by integrating complex data and generating a score, which ultimately describes the water quality status(Tiwari et al. 1985; Singh,D. F. 1992; Rao, S.N; 1997; Mishra et al.2001).GIS is 
a computer system for capturing, storing, querying, analyzing and displaying all types of geographical data. GIS allowsviewing, understanding, questioning, interpreting, and visualizing data in many ways that reveal relationships, patterns, and trends in the form of maps, globes, reports, and charts.GIS is an effective tool not only for collection, storage, management and retrieval of a multitude of spatial and non-spatial data, but also for spatial analysis and integration of these data to derive useful outputs and modeling (Gupta and Srivastava et al. 2010). It can be a powerful tool for developing solutions for water resources problems for assessing water quality, determining water availability, preventing flooding, understanding the natural environment and managing water resources on a local or regional scale (Tjandra et al. 2003). GIS is widely used for collecting diverse spatial data and for overlay analysis in spatial register domain to represent spatially variable phenomena (Bonham-Carter1996; Babikeretal.2004; Guptaand Srivastava2010). GIS-based, simple, and robust WQI is an essential tool for rapid transfer of information to water resources managers and the public. GIS can be useful for taking quick decisions as graphical representation would be easy to take a policy decision by the makers (Singh et al. 2013).

Nowadays, groundwater pollution has become a major problem in the world and need a regular monitoring of water bodies with required number of parameters for the welfare of the society. WQI is one of the most effective expressions which reflect a composite influence of contributing factors on the quality of water of any water system (Tiwari et al. 1986). The major objective of the present study to assess the suitability of groundwater quality for drinking purpose and generated water quality mapsusing GIS based on the available parameters from 33 locations in West Bokaro coalfield. This study will be usefull in current water resource planning and provide some basic data for the rational exploitation and use of water resources in the future.

\section{Study area}

The West Bokaro coalfield lies between $23^{\circ} 41^{\prime}$ to $23^{\circ} 52^{\prime} \mathrm{N}$ latitude and $85^{\circ} 24^{\prime}$ to $85^{\circ} 41^{\prime}$ E longitude (Fig.1) comprising an area of $207 \mathrm{Sq}$. $\mathrm{Km}$. It is geographically separated from the East Bokaro coalfield by conspicuous Lugu Hill (987 m). The entire coalfield falls in the Ramgarh District of
Jhrakhand.It is a major storehouse of medium coking coal. The coalfield is drained by Bokaro River passing through the central part of coalfield with easterly flows. Chutua River is the main tributaries of the Bokaro River which drains the northern hilly terrain of the coalfield. Chotha River is also the tributaries of Bokaro River which drains the Southern region of the coalfield. The West Bokaro coalfield is fourth from east among the Damodar Valley coalfield.

The West Bokaro coalfield forms a broad syncline with its trending E-W and exhibits a complete sequence of lower Gondwana formation which rest unconformably a basement rocks (Fig. 1). The Barakar Formation covers the major part of the coalfield and comprises of coarse to fine grained sand stone, pebbly conglomerates, gritty sandstones, grey shales, carbonaceous shales , fire clays and coal seams. The total of 29 correlates coal seams in Barker formation with 13 major seams (seam XIII to me and Karharbari formation contain only one seam (seam 0 ). The coals from West Bokaro- coalfield range from non-coking to almost prime coking type. The upper coal seams in the south western part are generally non - coking whereas the coal seams occurring in the northern part of the coalfield are more mature and medium coking to almost prime coking. In general improvement in the rank of coal from east to west and alsowith depthis observed.

The West Bokaro coalfield area experiences tropical climate and is characterized by very hot pre-monsoon and cold post- monsoon season. The month of May and mid June is the peak of the pre - monsoon season with an average maximum temperature of $44^{\circ} \mathrm{C}$, while December and January are the coldest months. The average annual rainfall of the district is $1418 \mathrm{~mm}$ and more than $85 \%$ of annual rainfall occurs during the four monsoon months (June to September).

\section{MATERIALS AND METHODS}

For the assessment of groundwater quality of the West Bokaro coalfields, systematic samplings were carried out duringpost-monsoon, 2012. Thirty three groundwater samples were collected from dug wells of the West Bokaro coalfield area (Fig. 1). The groundwater samples were collected in one liter narrow mouth pre-washed polyethylene bottles. Electrical conductivity (EC) and $\mathrm{pH}$ values were 
measured in the field using a portable conductivity and $\mathrm{pH}$ meter (Consort C831).In the laboratory, the water samples were filtered through 0.45 ìm Millipore membrane filters to separate suspended particles. Acid titration and were used to determine the concentration of bicarbonate $\left(\mathrm{HCO}_{3}^{-}\right)$in water (APHA 1998). Major anions $\left(\mathrm{F}^{-}, \mathrm{Cl}^{-}, \mathrm{SO}_{4}{ }^{2-}\right.$ and $\left.\mathrm{NO}_{3}{ }^{-}\right)$were analysed onion chromatograph (Dionex Dx-120) using anions AS12A/AG12 columns coupled to an anion self-regenerating suppressor (ASRS) in recycle mode. Major cations $\left(\mathrm{Ca}^{2+}, \mathrm{Mg}^{2+}\right.$, and $\left.\mathrm{Na}^{+}\right)$were measured by Atomic Absorption Spectrophotometer (Varian 680FS) in flame mode after calibrating the instrument with known standards. Three replicates were run for each sample for cation analysis and the instrument recalibrated after every 15 samples. An overall precision, expressed as percent relative standard deviation (RSD), was obtained below $10 \%$ for the entire samples.

\section{Water Quality Index}

WQI is defined as a rating reflecting the composite influence of different water quality parameters, which is calculated from the point of view of the suitability of groundwater for human consumption. The concept of WQI was firstly used by Horton (1965), and then developed by Brown et.al. (1970) and further improved by Deininger (Scottish Development Department, 1975). WQI a well known method as well as one of the most effective tools to express water quality that offers a simple, stable, reproducible unit of measure and communicate information about water quality to the policy makers and concerned citizens (Singh et al. 2013). It thus, becomes an important parameter for the assessment and management of ground water (Venkata and Reddy, 1995).WQI summarizes large amounts of water quality data into simple terms (e.g., excellent, good, bad, etc.) for reporting to management and the public in a consistent manner. The WQI can also be used for estimating water quality on-line, but the accuracy of the model depends upon the judicious selection of parameters.

Various researchers have considered the spatial groundwater quality index and the procedure of weighing is widely used to identify the quality of the water (Ckakraborthy et al., 2007; Bhaskar and

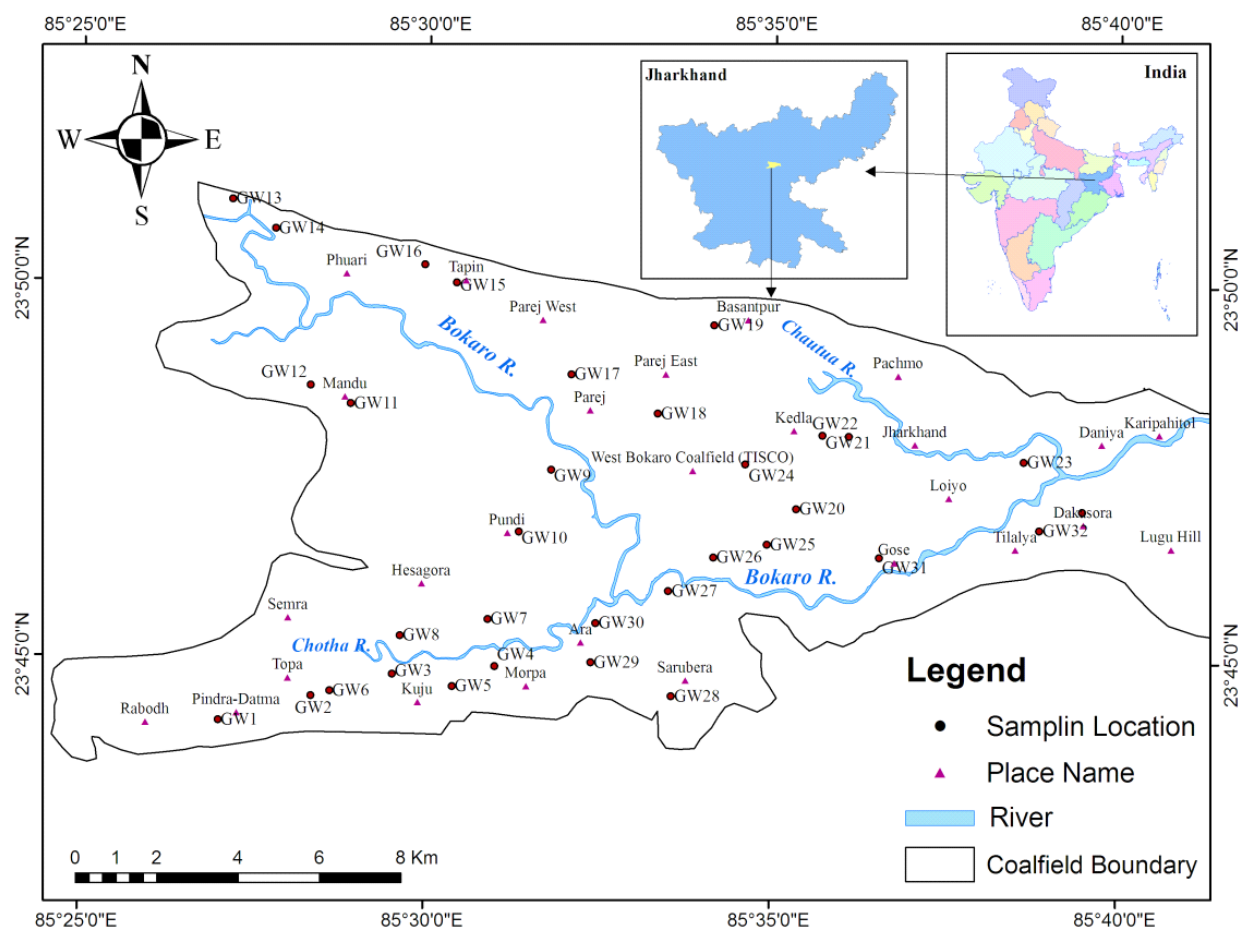

Fig. 1: Sampling location map of the West Bokaro coalfield 
Nagendrappa 2008; Ramakrishnalah et al. 2009, Sathish, 2011, Mufid al-hadithi 2012; Reddy and Patode 2013).

\section{GIS analysis}

Generated spatial distribution maps for the nitrate, sulphate, total hardness and total dissolved solid have been created for West Bokaro coalfield. Developed groundwater quality classification map from different thematic layers (Fig. 2a-c) based on Indian (ISI 2003) Standards for Drinking Water by using the ARC GIS 9.3 software. The classification of water quality is essential to an assessment of the suitability of water for domestic purposes.

Table 1: Relative weight of chemical parameters

\begin{tabular}{lccc}
\hline $\begin{array}{l}\text { Chemical } \\
\text { parameters }\end{array}$ & $\begin{array}{c}\text { Standards } \\
\text { (BIS) }\end{array}$ & $\begin{array}{c}\text { Weight } \\
(\text { Wi) }\end{array}$ & $\begin{array}{c}\text { Relative } \\
\text { weight (Wi) }\end{array}$ \\
\hline $\mathrm{pH}$ & 8.5 & 4 & 0.11 \\
$\begin{array}{l}\text { Total dissolved } \\
\text { solids }\end{array}$ & 500 & 5 & 0.13 \\
Fluoride & 1 & 5 & 0.13 \\
Chloride & 250 & 5 & 0.13 \\
Nitrate & 45 & 5 & 0.13 \\
Sulphate & 200 & 5 & 0.13 \\
Bicarbonate & 200 & 1 & 0.03 \\
Calcium & 75 & 3 & 0.08 \\
Magnesium & 30 & 3 & 0.08 \\
Total Hardness & 300 & 2 & 0.05 \\
& & $\Sigma W i=38$ & $\Sigma W i=1.00$
\end{tabular}

All concentration in $\mathrm{mg} / \mathrm{l}$, accept $\mathrm{pH}$.

Table. 2: Classification of WOI range and category of water

\begin{tabular}{ll}
\hline WQI Range & Category of water \\
\hline$<50$ & Excellent water \\
$50-100$ & Good water \\
$100-200$ & Poor water \\
$200-300$ & Very Poor water \\
$>300$ & Unfit for drinking purpose \\
\hline
\end{tabular}

\section{RESULTS AND DISCUSSION}

The $\mathrm{pH}$ of groundwater samples in the study area was found to be slightly acidic to slightly alkaline in nature. The $\mathrm{F}^{-}$and $\mathrm{Cl}^{-}$concentration measured in study area were below in the desirable limit while the $\mathrm{NO}_{3}^{-}$(Fig. 2a) and $\mathrm{SO}_{4}^{2-}$ (Fig. 2b) ion concentration is within both desirable and max. Permissible limits. The classification maps of TDS (Fig. 2c), $\mathrm{Ca}^{2+}$ and

Table. 3: Water Quality Index for Groundwater of West Bokaro coalfield

\begin{tabular}{|c|c|c|c|c|}
\hline $\begin{array}{l}\text { S. } \\
\text { No. }\end{array}$ & $\begin{array}{l}\text { Sample } \\
\text { Code }\end{array}$ & $\begin{array}{c}\text { Sample } \\
\text { Descripation }\end{array}$ & WQI & Description \\
\hline 1 & GW1 & Datma & 94 & Good \\
\hline 2 & GW2 & Topa & 66 & Good \\
\hline 3 & GW3 & Orla & 38 & Excellent \\
\hline 4 & GW4 & Murpa & 101 & Poor \\
\hline 5 & GW5 & Kuju & 69 & Good \\
\hline 6 & GW6 & Nayamore & 50 & Good \\
\hline 7 & GW7 & Hesagara & 92 & Good \\
\hline 8 & GW8 & Hesagara & 53 & Good \\
\hline 9 & GW9 & Pundi & 56 & Good \\
\hline 10 & GW10 & Pundi & 61 & Good \\
\hline 11 & GW11 & Mandu & 101 & Poor \\
\hline 12 & GW12 & Mandu & 114 & Poor \\
\hline 13 & GW13 & Charhi & 75 & Good \\
\hline 14 & GW14 & Charhi & 78 & Good \\
\hline 15 & GW15 & Tapin North & 38 & Excellent \\
\hline 16 & GW16 & Tapin & 131 & Poor \\
\hline 17 & GW17 & Parej East & 21 & Excellent \\
\hline 18 & GW18 & Parej & 44 & Excellent \\
\hline 19 & GW19 & Basantpur & 131 & Poor \\
\hline 20 & GW20 & Kedla & 83 & Good \\
\hline 21 & GW21 & Kedla & 93 & Good \\
\hline 22 & GW22 & Jharkahnd & 91 & Good \\
\hline 23 & GW23 & Laiyo & 54 & Good \\
\hline 24 & GW24 & Bhalghara & 43 & Excellent \\
\hline 25 & GW25 & Lahatungri & 122 & Poor \\
\hline 26 & GW26 & Mukund Beda & 63 & Good \\
\hline 27 & GW27 & Butbera & 49 & Excellent \\
\hline 28 & GW28 & Saruber & 54 & Good \\
\hline 29 & GW29 & Ara & 38 & Excellent \\
\hline 30 & GW30 & Ara & 129 & Poor \\
\hline 31 & GW31 & Chainpur & 53 & Good \\
\hline 32 & GW32 & Badgon & 87 & Good \\
\hline 33 & GW33 & Jageshvar Bihar & 51 & Good \\
\hline
\end{tabular}


$\mathrm{Mg}^{2+}$ vary between the desirable and permissible limit. The concentration of total hardness varies from soft to very hard categories.

\section{Estimation of WQI}

Water quality index (WQI) is defined as a technique of rating that provides the composite influence of individual water quality parameter on the overall quality of water (Singh et al. 2013). WQI is a mathematical equation used to transform a large number of water quality data into a single number (Stambuk-Giljanovic 1999). It is simple and easy to understandable for decision makers about quality and possible uses of any water body (Bordalo et al. 2001). For assessing the suitability of drinking water, the water quality data of the analyzed samples were compared with the prescribed drinking

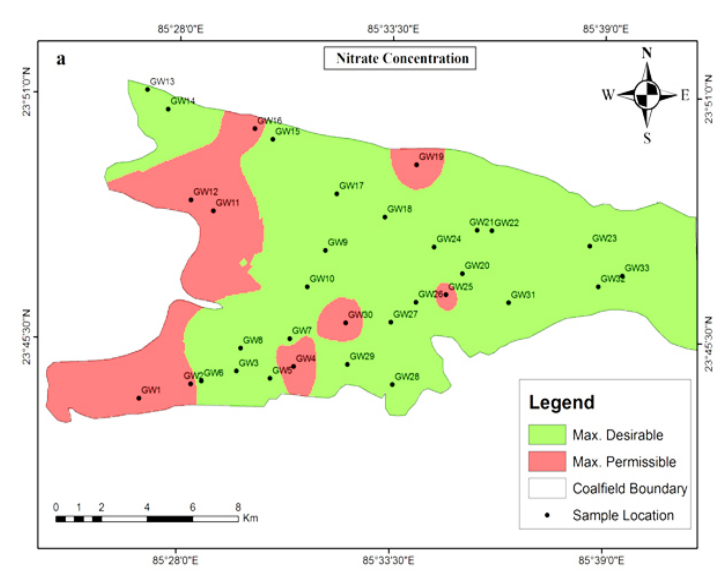

Fig. 2(A): Distribution of nitrate concentration in West Bokaro coalfield area

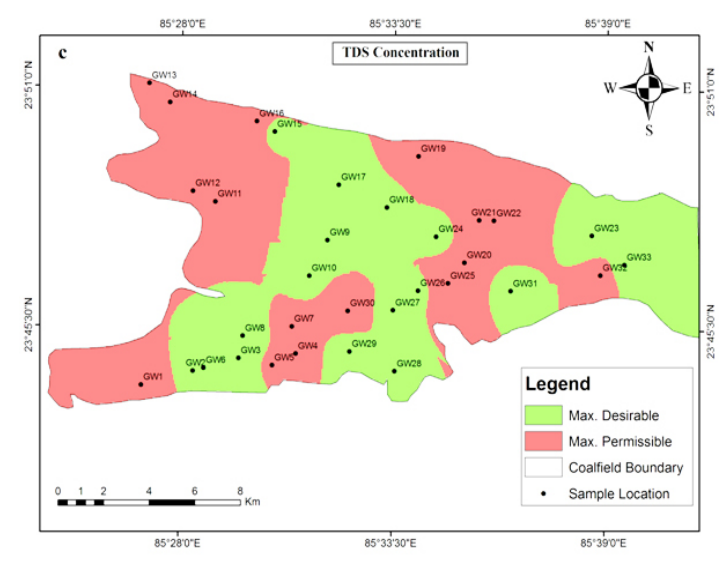

Fig. 2(C): Distribution of TDS concentration in West Bokaro coalfield area water standard of BIS 2003 (IS:10500) have been considered for the calculation of WQI. The Indian Standards as per ISI for the drinking water together with its corresponding status categories of WQI (Rao1997).In computing WQI three steps are followed. In the first step, each of the 10 parameters $\left(\mathrm{pH}, \mathrm{TDS}, \mathrm{F}^{-}, \mathrm{Cl}^{-} \mathrm{NO}_{3}^{-}, \mathrm{SO}_{4}{ }^{2-} \mathrm{HCO}_{3}^{-}, \mathrm{Ca}^{2+}, \mathrm{Mg}^{2+}, \mathrm{TH}\right)$ has been assigned a weight ( $w i$ ) according to its relative importance in the overall quality of water for drinking purposes (Table1)

The maximum weight of 5 has been assigned to the parameters like TDS, $\mathrm{F}^{-}, \mathrm{Cl}^{-} \mathrm{NO}_{3}^{-}$, and $\mathrm{SO}_{4}{ }^{2-}$ due to their major importance in water quality assessment (Vasanthavigar et al. 2010). $\mathrm{HCO}_{3}{ }^{-}$is given the minimum weight of 1 as it plays an insignificant role in the water quality assessment.

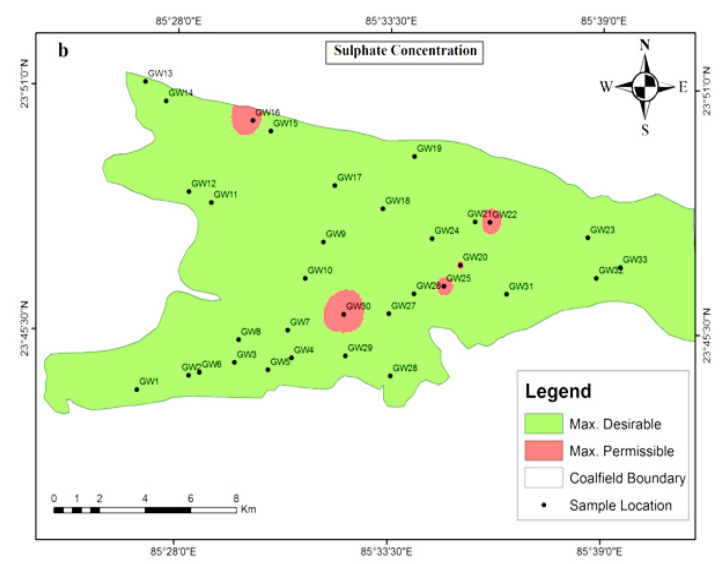

Fig. 2(B): Distribution of sulphate concentration in West Bokaro coalfield area

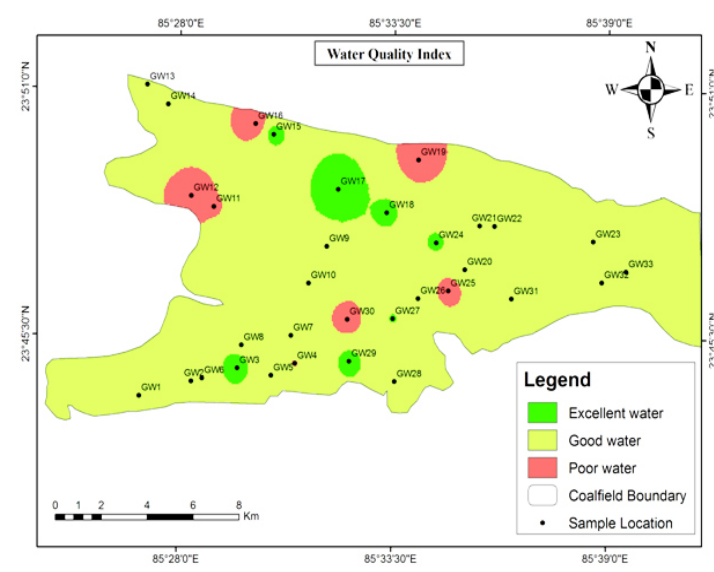

Fig. 3: Water quality index map of the West Bokaro coalfield area 
Other parameters like $\mathrm{Ca}^{2+}, \mathrm{Mg}^{2+} \mathrm{Na}^{+}$, and $\mathrm{TH}$ were assigned a weight $(w I)$ between 1 and 5 depending on their importance in water quality determination. In the second step, the relative weight $(W I)$ is computed from the following equation:

$$
W_{i}=w_{i} / \sum_{i=1}^{n} w_{i}
$$

Where, the $W_{-} i$ is the relative weight, $W i$ is the weight of each parameter and $\mathrm{n}$ is the number of parameters.

Calculated relative weight $(W I)$ values of each parameter are given in (Table1).

In the third step, a quality rating scale (q I) for each parameter is assigned by dividing its concentration in each water sample by its respective standard according to the guidelines laid down in the BIS 10500 (2003) and the result is multiplied by 100 :

$$
\mathrm{q}_{\mathrm{i}}=\left(\mathrm{C}_{\mathrm{i}} / \mathrm{S}_{\mathrm{i}}\right) \times 100
$$

Where, the $q i$ is the quality rating, $\mathrm{Ci}$ is the concentration of each chemical parameter in each water sample in $\mathrm{mg} \mathrm{L}^{-1}$ and $\mathrm{Si}$ is the BIS standard for each chemical parameter in $\mathrm{mg} \mathrm{L}^{-1}$ according to the guidelines of the BIS 10500 (2003).

For computing the WQI, the $S I$ is first determined for each chemical parameter, which is then used to determine the WQI as per the following equation

$$
\begin{aligned}
& S I_{i}=W_{i} \times q_{i} \\
& \mathrm{WQI}=\sum S I_{i}
\end{aligned}
$$

Where, the Sli is the sub-index of ith parameter, $q i$ is the rating based on concentration of ith parameter and $\mathrm{n}$ is the number of parameters

Water quality category, were determined on the basis of WQI. The computed WQI values range from 21 to 131 and average 73 respectively. WQI range and category of water can be classified
(Table2). The highest WQI were calculated from the samples collected from the Murpa, Mandu, Tapin, Basntpur, Lahatungi and Ara sampling locations (Table3). The reason for high WOI in the study area may be due to the natural and anthropogenic sources (mining activity, agriculture wastes, domestic sewage disposals etc.) Among all the of the groundwater samples, the percentage (\%) of WQI categories Excellent (21\%), Good (58\%) and Poor (21\%) were observed. More than half the location falls in Excellent to Good category (fig. 3).

\section{CONCLUSIONS}

The above study indicates that the groundwater of variable quality exists in the West Bokaro coalfield area. However, despite the coal mining and industry, an analysis of the chemistry of 33 dug wells sample indicates it is generally suitable for drinking purposes, except some locations. The WQI shows that $79 \%$ of groundwater samples were found as Excellent to Good category and can be used for direct consumption while $21 \%$ of water samples are the Poor category,samples show that the water is not suitable for direct consumption and requires treatment before its utilization.Suitable water treatment process such as water softening, ion exchange and reverse osmosis should be used to reduce the concentrations of contaminants in the study area.

\section{ACKNOWLEDGMENTS}

The authors are grateful to the Director, Central Institute of Mining and Fuel Research, Dhanbad to providing research facilities and also grateful to the Director, ISM for his kind support. One of the authors (Ashwani Kumar Tiwari) is grateful to Indian School of Mines/ MHRD/Government of India, for granting a great support. We are also thankful to Dr. Abhay Kumar Singh, Senior Scientist and Amit Ghosh, Project Assistant at Central Institute of Mining and Fuel Research for their support and encouragement. 


\section{REFERENCES}

1. APHA, Standard methods for the examination of water and waste water, 20th edn. American Public Health Association, Washington, DC. (1998).

2. Babiker I.S., Mohamed MAA., et al., Assessment of groundwater contamination by nitrate leaching from intensive vegetablecultivation using geographical information system, Environ Int, 29(8):10091017, (2004).

3. Bhaskar C. V.And Nagendrappa G., A comparative study of ground water quality and water quality index of certain selected areas situated around Tumkur city, Karnataka, Current World Environment, 3(1): 7582,(2008).

4. BIS., Indian standard drinking water specifications IS10500:1991, edition 2.2 (2003-2009), Bureau of Indian Standards, New Delhi,(2003).

5. Bonham-Carter G.F., Geographic information systems for geoscientists: modeling with GIS,Comput. Methods Geosci., 13: 1-50, (1996).

6. Bordalo A. A., Nilsumranchit W. and ChalermwatK., Water quality and uses of the Bangpakong river (Eastern Thailand), Water Research, 35(15): 3635-3642,(2001).

7. Bradon C. and Homman K., The cost of inaction: valuing the economy-wide cost of environmental degradation in India, Asia Environment Division, World Bank 7, October memo, (1995).

8. Brown R. M., McClelland N. I., Deininger R. A.and Tozer R. G., A water quality index: Do we dare?", Water \& Sewage Works, 117: 339-343,(1970).

9. Ckakraborthy S., Paul P. K. and Sikdar, P. K., Assessing aquifer vulnerability to arsenic pollutionusing DRASTIC and GIS of North Bengal Plain: A case study of English Bazar Block, Malda District, West Bengal, India, Journal of Spatial Hydrology, 7(1):101-121, (2007).

10. Gupta M. and Srivastava, P.K., Integrating GIS and remote sensing for identification of groundwater potential zones in the hilly terrain of Pavagarh, Gujarat, India, Water Int., 35: 233-245,(2010).

11. Horton R.K., An index number system for rating water quality,Journal-Water Pollution Control Federation, 37: 300-305,(1965).

12. Milovanovic M., Water quality assessment and determination of pollution sources along the Axios/ Vardar River, Southeastern Europe, Desalination,213: 159-173, (2007).

13. Mishra P. C. and Patel R.K., Study of the pollution load in the drinking water of Rairangpur, a small tribal dominated town of North Orissa, Indian J. Environment and Ecoplanning, 5(2): 293-298,(2001).

14. Mufid al-hadithi., Application of water quality index to assess suitability of groundwater quality for drinking purposes in Ratmao-Pathri Rao watershed, Haridwar District, India, $A m$. J. Sci. Ind. Res.,3(6): 395-402,(2012).

15. Ramakrishnalah C. R., Sadas hivalah C.and Ranganna G.,Assessment of water quality index for the groundwater in Tumkur Taluk, Karnataka state , India, E Journal of chemistry, 6(2): 523-530,(2009).

16. Rao N.S. Studies on Water Quality Index in Hard rock Terrain of Guntur District, Andhra Pradesh, India, National Seminar on Hydrogeology of Precambrian Terrains and Hard Rocks Areas, Dharwad, 129-134, (1997).

17. Reddy K. R. And Patode, R. S., Assessment of groundwater quality-A case study of Kondapur mandal, Medak district, Andhra Pradesh, Current World Environment, 8(2), (2013).

18. Sathish S. and Elango L., Groundwater Quality and Vulnerability Mapping of an Unconfined Coastal Aquifer,In. Journal of Spatial Hydrology, 11(1),(2011).

19. Scottish Development Department., Towards cleaner water. Edinburgh: HMSO, Report of a River Pollution Survey of Scotland,(1975).

20. Singh P. K., Tiwari A. K. and Mahato M. K., Qualitative Assessment of Surface Water of West Bokaro coalfield, Jharkhand by Using Water Quality Index Method International Journal of ChemTech Research, 5(5),(2013). 
21. Singh P. K., Tiwari A. K., Panigarhy B. P. and Mahato M. K., Water quality indices used for water resources vulnerability assessment using GIS technique: a review, International Journal Earth Science and Engineering, 6(6-1): 1594-1600,(2013).

22. Singh A. K., Raj Beenu., Tiwari A. K. and Mahato M. K., Evaluation of hydrogeochemical processes and groundwater quality in the Jhansi district of Bundelkhand region, India,Environmental Earth Science, 70(3): 1225-1247, (2013).

23. Singh D.F., Studies on the water quality index of some major rivers of Pune, Maharashtra Proceedings of the Academy of Environmental Biol., 1(1), 61-66, (1992).

24. Vasanthavigar M., Srinivasamoorthy K., Vijayaragavan K., Rajiv Ganthi R., Chidambaram S., Anandhan P., Manivannan R., and Vasudevan S., Application of water quality index for groundwater quality assessment: Thirumanimuttar sub-basin, Tamilnadu, India, Environmental monitoring and assessment 171(1-4): 595-609 (2010)

25. Stambuk-Giljanovic N., Water quality evaluation by index in Dalmatia, Water
Research, 33(16): 3423-3440,(1999).

26. Tiwari A. K. and Singh A. K., Hydrogeochemical investigation and groundwater quality assessment of Pratapgarh district, Uttar Pradesh, Journal of the Geological Society of India 83(3): 329-343,(2014).

27. Tiwari T.N., and Mishra M.A., A preliminary assignment of water quality index of major Indian rivers, Indian J. Environmental Protection, 5: 276-279,(1985).

28. Tiwari T.N., Das, S. C. and Bose P.K., Water Quality Index for the river Jhelum in Kashmir and its seasonal variations, Poll Res., 5: 1-5. (1986).

29. Tjandra F. L., Kondhoh A. andMohammed A.M.A., A conceptual database design for hydrology using GIS, In: Proceedings of Asia pacific association of hydrology and water resources, 13-15 March, Kyoto, Japan,(2003).

30. Venkata., Mohan, S, Jayrama. and Reddy S., Assessment of overall water quality of Tirupati, Poll. Res.,14(3): 275-282, (1995).

31. WHO.,Water, sanitation and hygiene links to health-facts and figures, World Health Organization, Geneva, (2004). 